\title{
Building America
}

Guidance for Identifying

and Overcoming Code,

Standard, and Rating

Method Barriers

September 2013 



\title{
DISCLAIMER
}

This report was prepared as an account of work sponsored by an agency of the United States Government. Neither the United States Government nor any agency thereof, nor Battelle Memorial Institute, nor any of their employees, makes any warranty, express or implied, or assumes any legal liability or responsibility for the accuracy, completeness, or usefulness of any information, apparatus, product, or process disclosed, or represents that its use would not infringe privately owned rights. Reference herein to any specific commercial product, process, or service by trade name, trademark, manufacturer, or otherwise does not necessarily constitute or imply its endorsement, recommendation, or favoring by the United States Government or any agency thereof, or Battelle Memorial Institute. The views and opinions of authors expressed herein do not necessarily state or reflect those of the United States Government or any agency thereof.

\author{
PACIFIC NORTHWEST NATIONAL LABORATORY \\ operated by \\ BATTELLE \\ for the \\ UNITED STATES DEPARTMENT OF ENERGY \\ under Contract DE-AC05-76RL01830
}

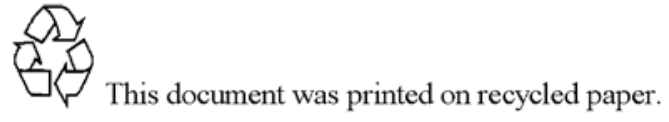

(9/2003) 



\section{Building America Guidance for Identifying and Overcoming Code, Standard, and Rating Method Barriers}

PC Cole

MA Halverson

September 2013

Prepared for

the U.S. Department of Energy

under Contract DE-AC05-76RL01830

Pacific Northwest National Laboratory

Richland, Washington 99352 



\section{Contents}

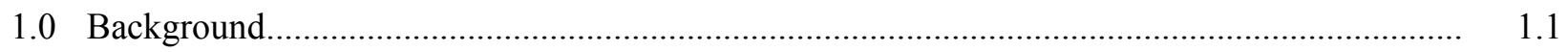

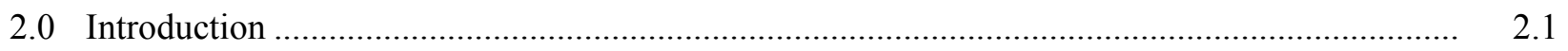

3.0 Identify and Characterize the Barrier .......................................................................

3.1 Barrier Identification, Method 1: Leverage Existing Knowledge of BA Research Teams, National Laboratories, Partners, and Industry ….............................................. 3.1

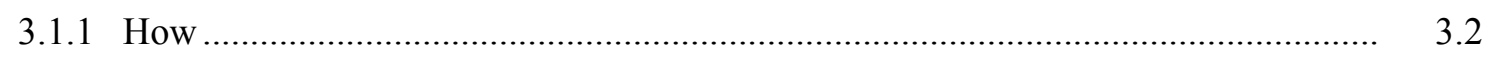

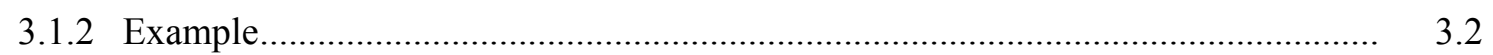

3.2 Barrier Identification, Method 2: Structured Consideration of Relevant Codes,

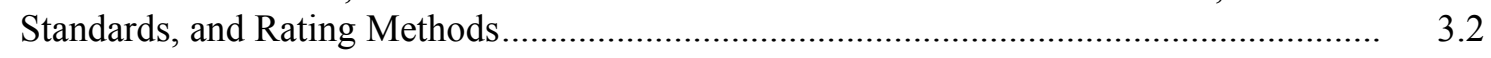

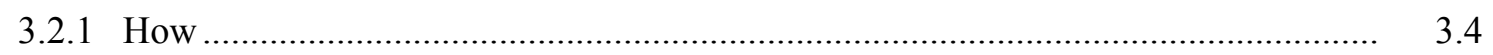

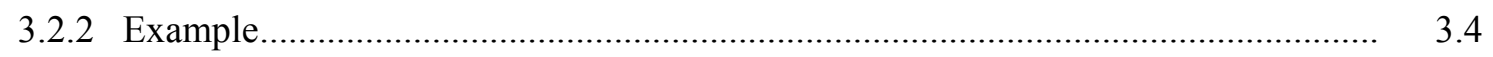

3.3 Barrier Identification, Method 3: Systematic Evaluation against an Impacts Checklist .... $\quad 3.7$

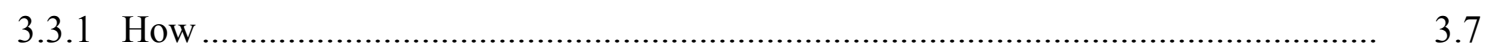

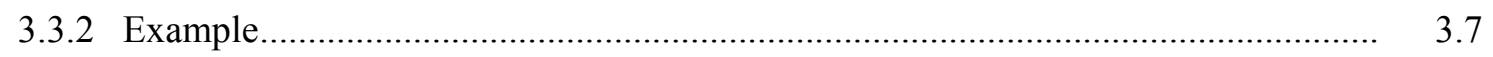

3.4 What Should Users Do if They Suspect the Existence of a Barrier? ................................ 3.9

4.0 Overcome the Barrier ..............................................................................................

4.1 Overcoming Barriers, Approach 1: Search Existing Materials ......................................... 4.1

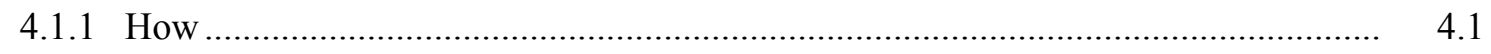



4.2 Overcoming Barriers, Approach 2: Utilize Alternative Materials and Methods Clauses and/or Plead Special Circumstances ......................................................................... 4.2

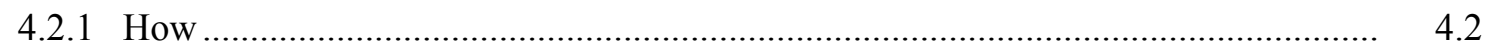

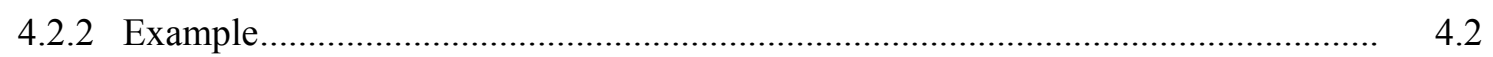

4.3 Overcoming Barriers, Approach 3: Direct Enforcement Officials to Newer Versions of Code, Standard, or Rating Method ....................................................................................

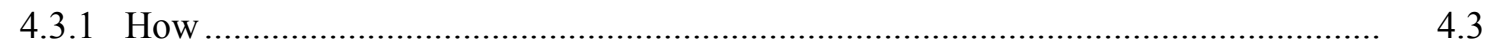

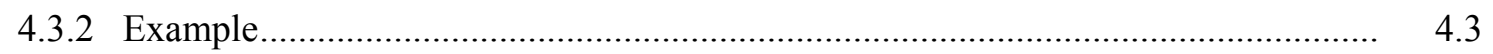

4.4 Overcoming Barriers, Approach 4: Obtain a Favorable Interpretation ............................... 4.3

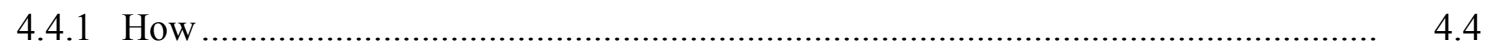

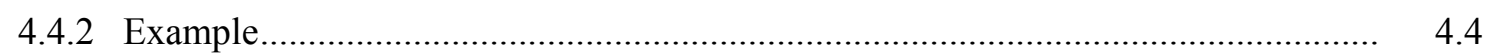

4.5 Overcoming Barriers, Approach 5: Change the Code, Standard, or Rating Method .......... 4.4



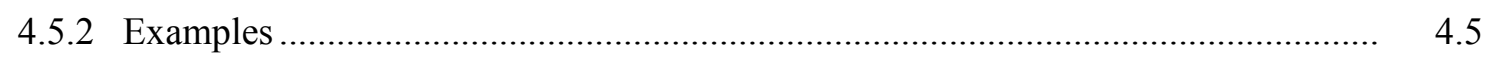

5.0 Building America CSI Team Involvement ................................................................... 5.7

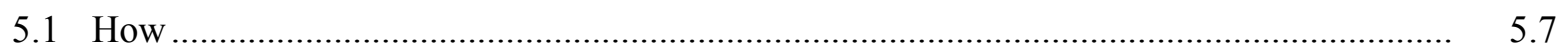

Appendix A - List of Codes and Standards and List of Questions for Identification of Barriers ........ A.1

Appendix B - Alternative Methods and Material Documentation Form Used in Pierce County, Washington

B. 1 
Appendix C - Alternative Methods and Material Documentation, ICC-ES Flow Chart........ C. C.1

Appendix D - International Code Development Process Flow Chart ……......................... D. D

Appendix E - Standards Development Process Flow Chart .................................................. E.1 


\section{Figures}

3.1 Example Barrier Identification Illustration of Various Codes ................................................ 3.3

3.2 Example Barrier Identification Illustration of Various Standard Organizations.......................... 3.3

3.3 Example Barrier Identification Illustration of Various Rating Methods ................................... 3.4 



\subsection{Background}

The U.S. Department of Energy's (DOE) Building America program implemented a new Codes and Standards Innovation (CSI) Team in 2013. The Team's mission is to assist the Building America (BA) program to identify and resolve possible barriers between BA innovations and the various codes and standards that govern the construction of residences. In February 2013, an initial CSI Planning meeting was held to facilitate creating a clear vision for success, actions, and responsibilities. The goal of the meeting included:

1. Bringing together BA team and national laboratory leaders and other experts to assess and address codes and standards $(\mathrm{C} \& \mathrm{~S})$ challenges

2. Building on past successes in $\mathrm{C} \& \mathrm{~S}$ innovations resulting from adoption of new technologies, particularly those influenced by BA experts

3. Developing an understanding of $\mathrm{C} \& \mathrm{~S}$ issues confronting high-performance home innovations; and

4. Creating an organized, collaborative method to identify, prioritize, and efficiently apply BA resources to accelerate the deployment of high-performance innovations.

A draft CSI Roadmap was completed in September, 2013 to help the team set goals and plan activities. The roadmap documents the results of the February meeting, suggested key actions, subsequent key actions taken, and a proposed follow-up plan to address key issues related to building codes and standards.

This draft guidance document was prepared using the input from the meeting summarized in the draft CSI Roadmap to provide BA research teams and partners with specific information and approaches to identifying and overcoming potential barriers to Building America (BA) innovations arising in and/or stemming from codes, standards, and rating methods. For more information on the BA CSI team, please email: $\underline{\text { CSIteam@pnnl.gov }}$ 



\subsection{Introduction}

High-performance homes are subject to an ever increasing number of codes, standards, and rating methods. For example, there are codes that regulate the amount of insulation that should be in a wood framed wall, other codes that regulate the thickness of plastic foam insulation on the outside of the wall, and still other codes that regulate how much outside air should be brought into a home and how. There are also standards and rating methods that regulate everything from how a duct should be tested to how the energy rating on a piece of air conditioning equipment should be determined.

Codes, standards, and rating methods are invariably written to regulate existing processes, practices and methodologies. Codes and standards do not typically speculate about what the future of construction might be and how those future processes, practices, and methods might be regulated. It is hard enough to figure out how to regulate existing practice in a compact and understandable document, so it is not wonder regulation of future practice is left to future codes and standards. For BA, the future is now in terms of high-performance residential building practices. BA teams and partners are creating new technologies and construction techniques that frequently are not properly addressed in codes and standards and/or that code officials and other enforcement/compliance entities are not familiar or comfortable with. Some of those codes, standards, and rating methods contain barriers to implement BA innovations. Overcoming C\&S barriers to energy-efficient innovation speeds up commercialization and market acceptance of improved technologies.

This document provides guidance on methods and approaches to identifying and overcoming $\mathrm{C} \& \mathrm{~S}$ barriers and examples illustrating how each one has been or can be implemented. (The term "user" is used throughout this document and is defined as, any person involved in the design or construction process who encounters resistance to or prohibition of specifying a BA innovation due to code, standard, or rating system issues.) Sections 3 and 4 present a logical process a user can use to identify, characterize, and overcome codes, standards, and rating methods barriers to innovations. Section 3 outlines a systematic process for identifying a barrier and characterizing it according to the code or standard applicable provision, the nature of the barrier (e.g., prohibited or discouraged by code), and whether the provision is explicit about the innovation. Section 4 outlines a systematic process for overcoming the identified barriers (e.g., obtaining a favorable interpretation). 



\subsection{Identify and Characterize the Barrier}
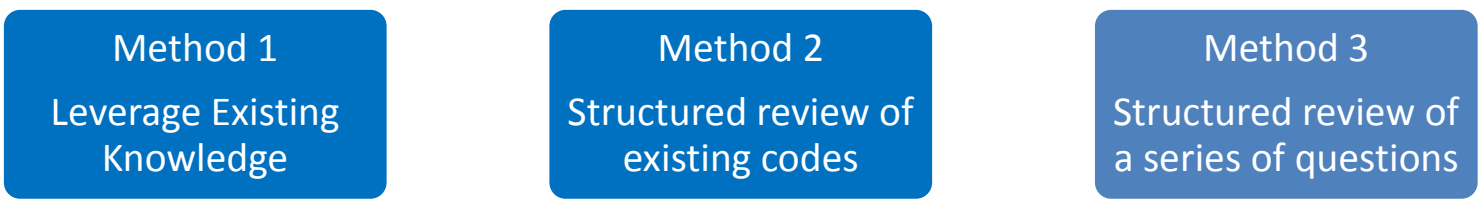

The first step is identifying the barrier and tracing it to the relevant codes, standards, and/or rating methods. Barriers can arise at any time during the design, construction, or inspection phases of construction and the earlier the barrier can be identified, the less disruption there will be to the overall construction process. BA's CSI team has further defined barriers as any requirement in a code, standard, or rating method that

1. Requires the wrong thing,

2. prohibits a BA innovation,

3. discourages a BA innovation, or

4. does not encourage a BA innovation that would lead to better, more efficient homes.

The following are three recommended methods of identifying barriers:

1. Leverage existing knowledge embodied in the BA research teams, national laboratories, partners, and industry about code and standard issues that might be associated with the innovation. For example, there are BA research team staff who regularly work on the construction site and interact with code officials and therefore have unique insight;

2. Structured review of existing codes that might apply to, interact with, or overlap with the innovation; and

3. Structured review of a series of questions that attempt to identify potential barriers that might apply to the innovation.

The key to identification of a barrier is knowing where barriers can exist and digging through existing research materials (e.g., a list of codes, standards, or series of questions) and/or contacting and discussing with BA research teams until the user determines if there is a barrier or not.

\subsection{Barrier Identification, Method 1: Leverage Existing Knowledge of BA Research Teams, National Laboratories, Partners, and Industry}

BA research teams and partner organizations consist of professionals that have unique and detailed knowledge on building science, building design, and building construction. That knowledge includes codes and standards. The expertise is distributed among the professionals, but it is worth the effort to seek out those with specific experience relevant to a given technology, code, or barrier. 


\subsubsection{How}

1. Discuss the innovation within your own BA research team (if applicable).

2. Contact BA research teams and/or national laboratories to discuss the innovation using the links to the research teams and national laboratories listed at http://www1.eere.energy.gov/buildings/residential/ba research_teams.html

3. Contact CSI at CSIteam@pnnl.gov to discuss the innovation and possible barriers with CSI team members.

\subsubsection{Example}

One example of barrier identification from existing knowledge occurred when the CSI team began to review the BA taxonomy of innovations. One innovation that immediately stood out was the use of electro-chromic windows. Electro-chromic windows are part of the BA taxonomy as element TE.1.2. This innovation addressed a barrier, in the commercial codes and standards (International Energy Conservation Code/IECC and American Society of Refrigerating, AirConditioning Engineers /ANSI/ASHRAE/IES Standard 90.1) by a manufacturer of electro-chromic windows. The barrier was that the commercial code called for a single SHGC (solar heat gain coefficient) value for fenestration and dynamic glazing products have a range of SHGC values. This barrier was overcome for commercial codes in Standard 90.1-2010 and in the 2012 IECC. (See Section C402.3.3.5 Dynamic glazing in the 2012 IECC.) Unfortunately, similar language was not incorporated into the residential portion of the 2012 IECC, so electro-chromic windows can be expected to face a barrier in residential buildings. Having identified this barrier, it may be possible to convince a code official that because the commercial portion of the IECC allows electro-chromic windows, it is reasonable to permit them for residential as well, even if it is not specifically mentioned in the residential portion of the code. This innovation had been specifically targeted by a member of DOE's Building Energy Codes Program (BECP) during development of the commercial standard and code; recognizing and contacting such experienced staff is an important step in ensuring BA innovations are not held up by code issues.

\subsection{Barrier Identification, Method 2: Structured Consideration of Relevant Codes, Standards, and Rating Methods}

A second method of identifying barriers is to evaluate an innovation against a list of the relevant codes, standards, and rating systems, considering whether each contains potential barriers. Consultation between BA research team members, other BA research teams, industry partners, or with the CSI team may be necessary. This approach is illustrated in Figures 3.1, 3.2, and 3.3 for the families of building codes, standard organizations, and various rating methods. In each figure, the boxes represent examples of the different codes, standards or rating methods, in no particular order, to be considered in the barrier identification process. 


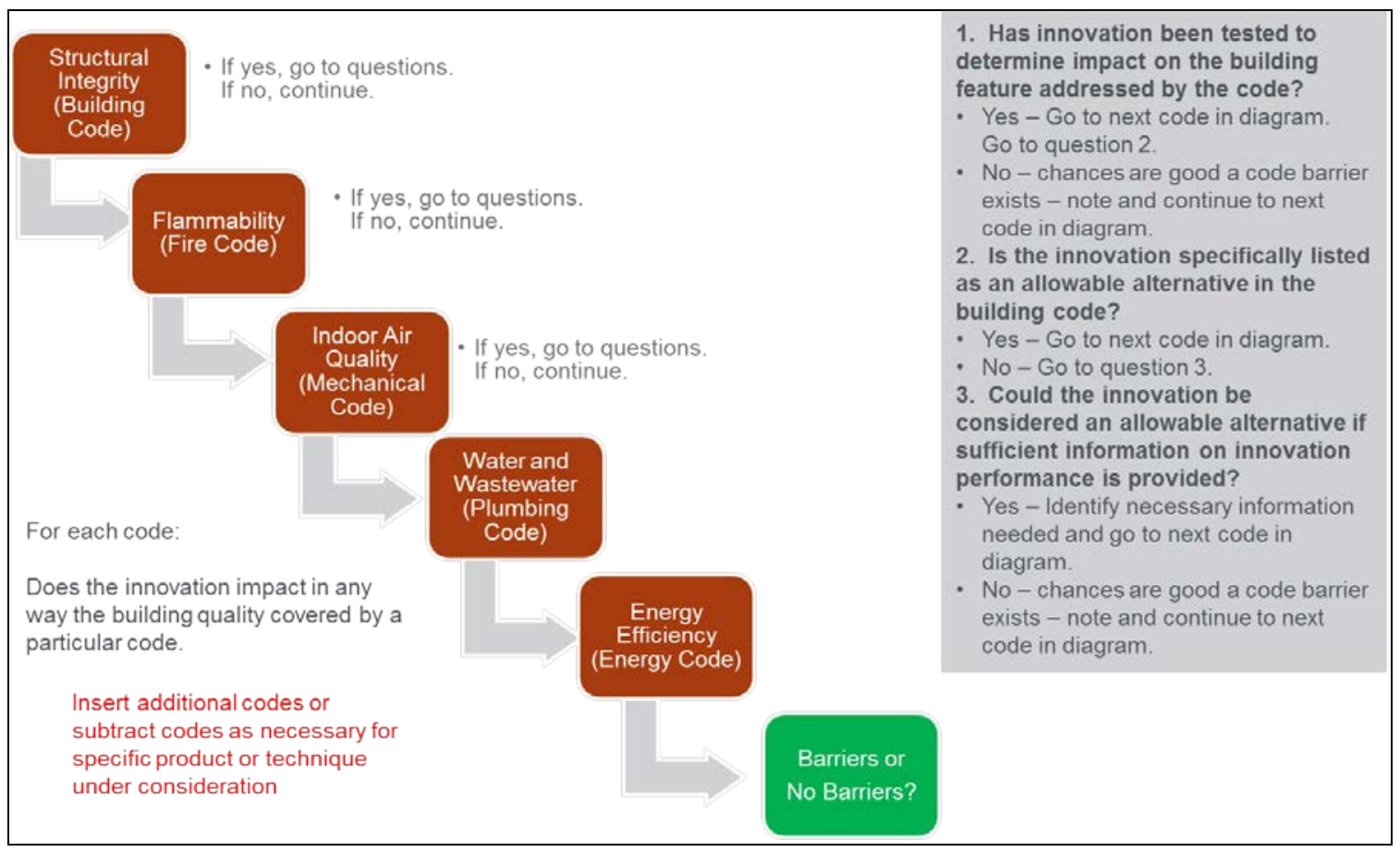

Figure 3.1. Example Barrier Identification Illustration of Various Codes (This is not a comprehensive list of all codes that may apply.)

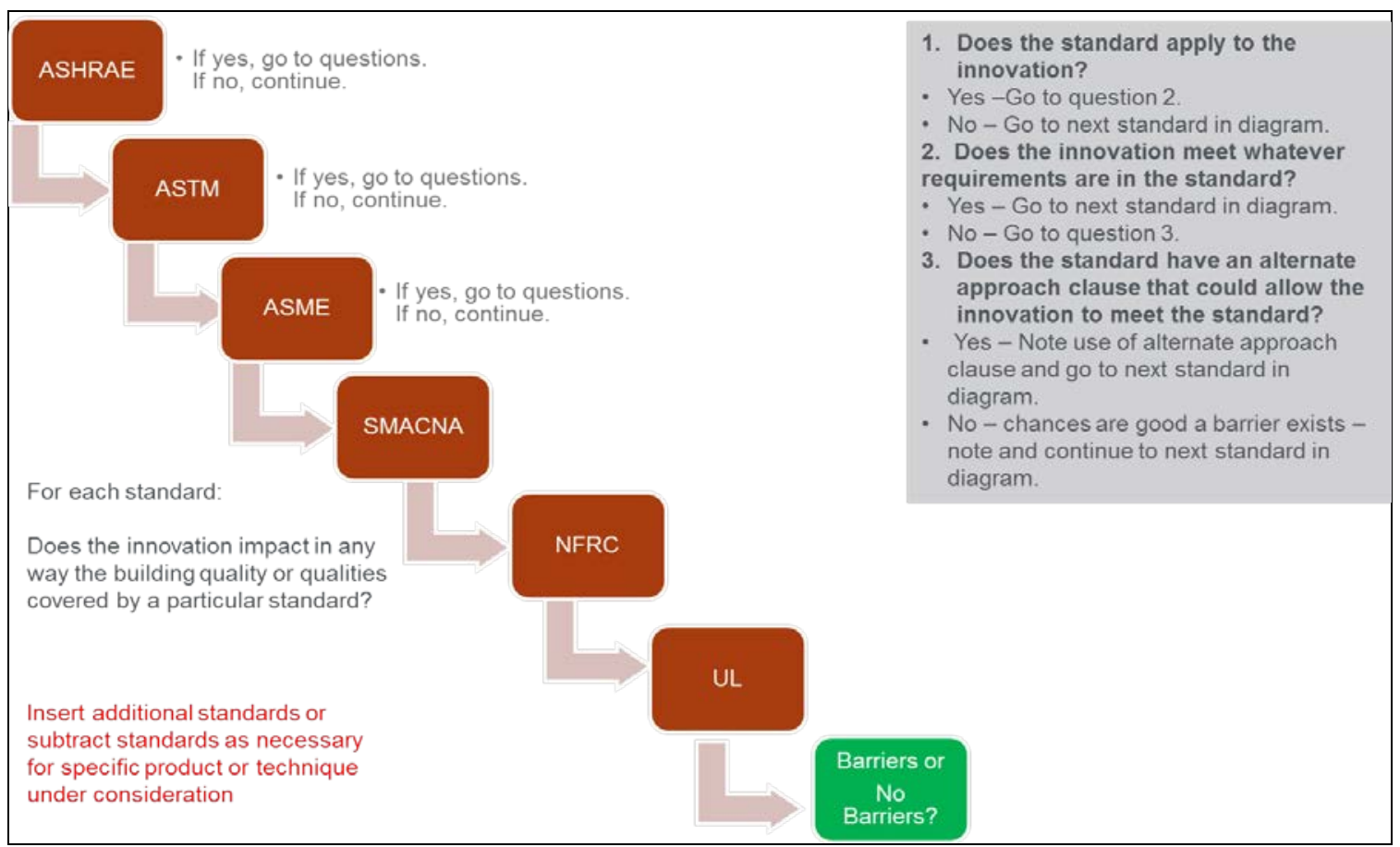

Figure 3.2. Example Barrier Identification Illustration of Various Standard Organizations (This is not a comprehensive list of all standard organizations that may apply.) 


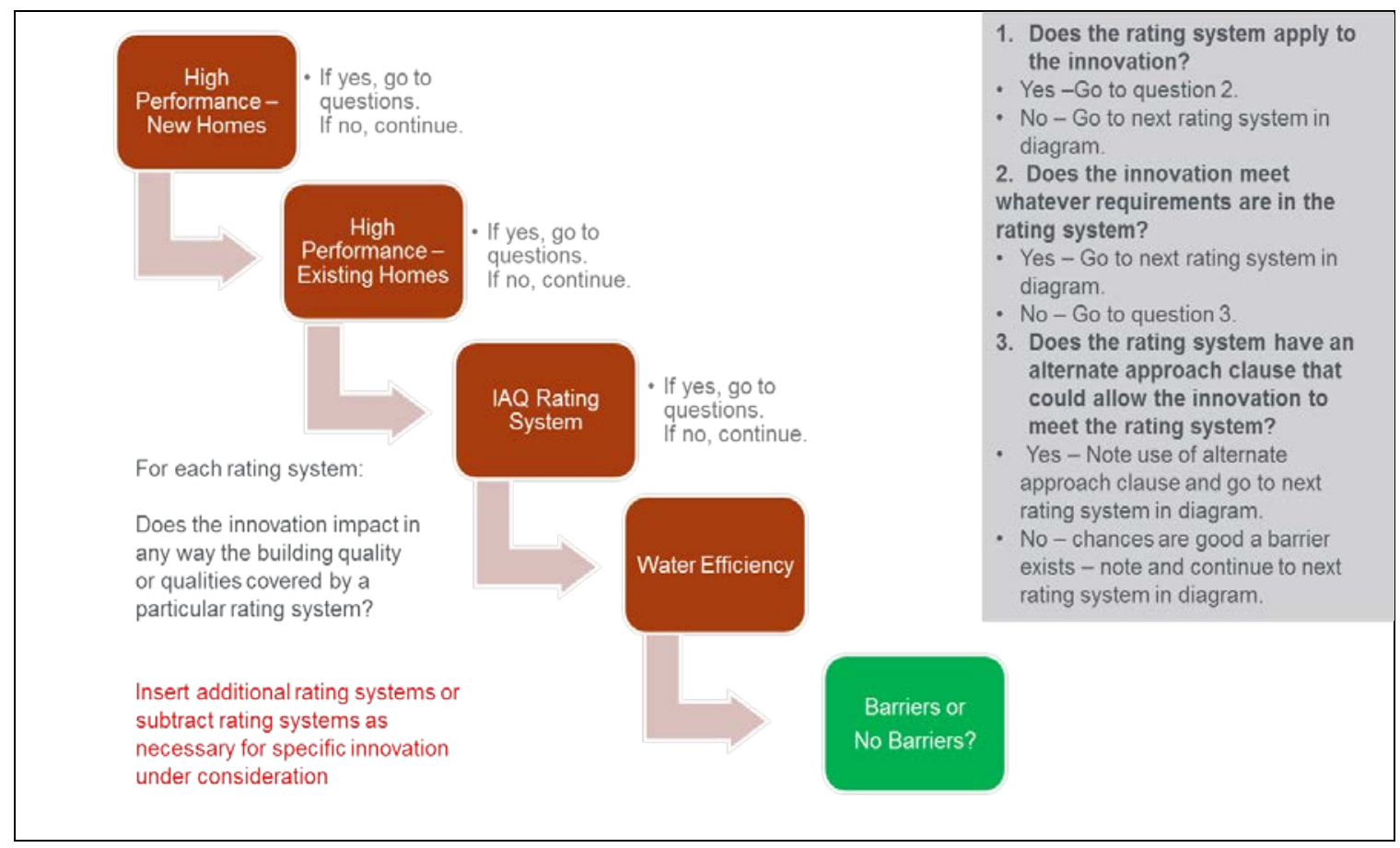

Figure 3.3. Example Barrier Identification Illustration of Various Rating Methods (This is not a comprehensive list of all rating methods that may apply.)

\subsubsection{How}

The CSI team maintains several lists of codes, standards, and rating methods that could apply to construction techniques and innovations used in BA projects. Tables A-1, A-2, and A-3 in Appendix A contain forms that may be used to implement this method of barrier identification. These tables contain the current lists of codes, standards, and rating methods that are routinely dealt with by BA research teams. It is anticipated that BA researchers and their partners will help expand or contract the list as necessary.

\subsubsection{Example}

The lists of codes, standards, and rating methods developed by CSI are new enough that they have not been officially used by BA research teams, partners, or other users as of yet. However, an example taken from the CSI Summit meeting in Washington D.C. shows how these lists might be used. That meeting included a discussion of a list of BA innovations known to face codes and/or standards barriers. Among the many items on that list, attendees discussed three in detail: ventilation, plastic ducts, and air tight air barriers for fire-rated assemblies. For this example, an air conditioner using propane and carbon dioxide is illustrated below. The initial barrier type was identified as being prohibited by code (propane is currently disallowed by the code). There also might be other codes, standards or rating methods that apply to this issue.

The approach would be to step through the codes and standards in Tables A-1 and A-2 and the rating methods in Table A-3 one at a time to identify which ones might apply. Through further research and consultation with a member of the CSI team, it was noted that most residential sized 
HVAC (heating, ventilation, and air conditioning) equipment is covered by national minimum efficiency manufacturing standards developed by the US DOE. Current and proposed requirements may be found on DOE's Appliance and Equipment Standards webpage at http://www.1.eere.energy.gov/buildings/appliance_standards/standards test_procedures.html. Residential products are listed under the category of "Consumer Products". Alternatively, residential sized equipment efficiency is listed in the commercial HVAC tables in the 2012 IECC. For air-cooled air conditioners less than $65,000 \mathrm{Btu} / \mathrm{h}$ (a typical size for residential products), the performance requirements is 13.0 SEER and the test procedure is AHRI 210/240. This information may be found in Table C403.2.3(2) of the 2012 IECC. Other residential HVAC equipment is listed in the other tables found in Section C403 of the 2012 IECC. Initial questions that might reveal potential barriers to this proposed propane/carbon dioxide air conditioner include:

a. Does the air conditioner meet the required efficiency?

b. Has it been tested by AHRI 210/240?

c. Can it be tested by AHRI 210/240?

If the answer to any of these questions is no (or unknown), then a barrier exists or might exist. With regard to other codes that might impact this type of air conditioner, it is obvious that propane is flammable, so it is possible/likely the fire code might have requirements regarding propane being used as a refrigerant. A search of the text of the fire code for the words "propane" or "refrigerant" might reveal that. It is also possible that there are lists of approved refrigerants for mechanical equipment in the mechanical code and that should be researched as well. But knowing that the energy, fire, or mechanical codes may be an issue is only a first step. Digging into what exactly those codes say about propane used as a refrigerant would be the next step.

For this example, Table A-2 is duplicated here and completed as if by a user. Note that all codes are identified as sources of potential conflict by using a bold font on "Yes", "No", or "NA" and only those codes that are a "Yes" have a description of the potential conflict.

Looking online at this topic, it appears that one of the main barriers to the use of propane as a refrigerant is the Environmental Protection Agency (EPA) which has not approved the use of propane as a refrigerant in systems not originally designed for propane. (See

http://yosemite.epa.gov/opa/admpress.nsf/bd4379a92ceceeac8525735900400c27/61416ea839b0618e8525 7b9b0065aec0! OpenDocument). 
Table A-2. Alternative Documentation Form for Code and Standard Barriers - Example

Air Conditioner with Propane and Carbon Dioxide

The residential air conditioner should be charged with a mixture of propane and carbon dioxide.

\begin{tabular}{|c|c|c|c|}
\hline Topic & Building Code and Standards & $\begin{array}{l}\text { Potential } \\
\text { Conflict }\end{array}$ & Description of Potential Conflict \\
\hline Building Code & International Building Code (IBC) & Yes/No/NA & (Describe) \\
\hline Existing Buildings & International Existing Building Code (IEBC) & Yes/No/NA & (Describe) \\
\hline Existing Buildings & ASHRAE Standard 100 & Yes/No/NA & (Describe) \\
\hline Energy & International Energy Conservation Code (IECC) & Yes/No/NA & Equipment performance and test method \\
\hline Energy & ASHRAE Standard 90.2 & Yes/No/NA & Equipment performance and test method \\
\hline Electrical & International Electrical Code (IEC) & Yes/No/NA & (Describe) \\
\hline Electrical & National Electrical Code (NEC) & Yes/No/NA & (Describe) \\
\hline Fire & International Fire Code (IFC) & Yes/No/NA & Increased amount of propane in house \\
\hline Fire & NFPA Fire Codes (specify) & Yes/No/NA & Increased amount of propane in house \\
\hline Fuel Gas & International Fuel Gas Code (IFGC) & Yes/No/NA & Increased amount of propane in house \\
\hline Green Buildings & International Green Construction Code & Yes/No/NA & (Describe) \\
\hline Green Buildings & ASHRAE Standard 189.1 & Yes/No/NA & (Describe) \\
\hline Green Buildings & National Green Building Standard & Yes/No/NA & Equipment performance and test method? \\
\hline Ventilation & International Mechanical Code (IMC) & Yes/No/NA & (Describe) \\
\hline Ventilation & ASHRAE Standard 62.1 & Yes/No/NA & (Describe) \\
\hline Ventilation & ASHRAE Standard 62.2 & Yes/No/NA & (Describe) \\
\hline Performance & ICC Performance Code & Yes/No/NA & (Describe) \\
\hline Plumbing & International Plumbing Code (IPC) & Yes/No/NA & (Describe) \\
\hline Sewage & International Private Sewage Disposal Code (IPSDC) & Yes/No/NA & (Describe) \\
\hline Maintenance & International Property Maintenance Code (IPMC) & Yes/No/NA & (Describe) \\
\hline Residential Buildings & International Residential Code (IRC) & Yes/No/NA & Check content to see potential impacts \\
\hline $\begin{array}{l}\text { Swimming Pools and } \\
\text { Spas }\end{array}$ & International Swimming Pool and Spa Code (ISPSC) & Yes/No/NA & (Describe) \\
\hline Zoning & International Wildland-Urban Interface Code (IWUIC) & Yes/No/NA & (Describe) \\
\hline Zoning & International Zoning Code (IZC) & Yes/No/NA & (Describe) \\
\hline
\end{tabular}




\subsection{Barrier Identification, Method 3: Systematic Evaluation against an Impacts Checklist}

A third method of identifying code, standard, and rating method barriers is to evaluate an innovation against a list of questions designed to highlight the innovation's direct and indirect impacts on a building. In this case, the list of relevant questions addresses the sorts of things that might be expected to be covered in some codes. Topics like health, life safety, fire resistance and flammability, structural integrity, electrical safety, and energy efficiency can be addressed in these questions.

\subsubsection{How}

The CSI team maintains a checklist of questions that could be used for this method (see Table A.4 in Appendix A). It is anticipated that BA researchers and their partners will help expand or contract the list as necessary.

\subsubsection{Example}

The same example as was used for Barrier Identification Method 2 could be used here-air conditioner using propane and carbon dioxide. Instead of working through codes and standards, users could step through the questions in Table A.4. Looking at that table (repeated here for the example) the user might generate the following answers as shown in BOLD CAPITAL FONT:

1. Does the BA innovation impact the structural strength of the home in any way? (If no, continue to next numbered question. If yes, continue with the subset of questions below.) NO

a. Does it impact the ability of the home to withstand snow loads?

b. Does it impact the ability of the home to withstand wind loads?

c. Does it impact the ability of the home to withstand earthquake loads?

d. Does it impact the ability of the home to withstand flooding?

2. Does the BA innovation impact the fire resistance of the home in any way? YES

a. Does it increase the likelihood of fire ignition? MAYBE

b. Does it increase the likelihood of flame spread within the home? MAYBE

c. Does it increase the load of combustible material? YES

d. Does it increase the likelihood of flame spread to neighboring structures? NO

3. Does the BA innovation impact the ability of fire and emergency personnel to access the home in any way? NO

a. Does it involve electrical wiring in a place where it would not be expected in a typical new home?

b. Does it make it harder for fire/emergency personnel to access the inside of the home?

4. Does the BA innovation impact the durability of the home in any way? NO

a. Does it impact moisture resistance?

b. Does it impact termite resistance?

c. Does it increase the potential for mold? 
5. Does the BA innovation impact the indoor air quality of the home in any way? NO, UNLESS THE AIR CONDITIONING UNIT LEAKS REFRIGERANT

a. Does it impact the ability of the home to bring in outside air?

b. Does it impact the ability of the home to exhaust inside air?

c. Does it impact the ability of the home to mix inside air with outside air?

d. Does it impact the ability of the home to "dilute" spot sources of contaminants?

e. Does it impact the humidity levels in the home?

f. Does it impact of use of combustion appliances in any way (gas stoves, gas furnaces, fire places, wood stoves)?

g. Does it introduce new sources of contaminants into the home?

6. Does the BA innovation impact the water usage of the home in any way? NO

a. Does it impact indoor water quality?

b. Does it impact indoor water quantity?

c. Does it impact the time it takes hot water to reach a faucet or showerhead?

d. Does it impact exterior water quality?

e. Does it impact exterior water quantity?

f. Does it impact exterior runoff?

7. Does the BA innovation impact sewage from the home in any way? NO

a. Will there be more sewage?

b. Will there be the potential for more clogs?

8. Does the BA innovation impact the dimensions of the home in any way? NO

a. Does it lead to thicker walls (meaning thicker door frames, window sills, smaller interior space for same exterior space, etc?)

b. Does it lead to higher rooflines?

9. Does the BA innovation require changes to existing construction practice? NO

a. Does it require new techniques?

b. Does it require new materials?

c. Does it require new equipment?

d. Does it require new inspection or testing?

10. Does the BA innovation impact the energy efficiency of the home in any way? MAYBE - DEPENDS ON WHETHER OR NOT UNIT MEETS FEDERAL STANDARDS

11. Would the BA innovation be considered "green"? UNKNOWN

12. Would the BA innovation impact the cost of the home in any way? UNKNOWN

Note that the answers to the list of questions would direct the user to look at the fire codes and energy codes and also perhaps the mechanical code, which was the result of Barrier Identification Method 2 as well. Any of the Barrier Identification Methods should ultimately lead to the same result. 


\subsection{What Should Users Do if They Suspect the Existence of a Barrier?}

The three barrier identification methods listed above can help in considering various codes, standards, or rating methods that might impact their innovations. However, all these methods are ultimately dependent on someone looking at the text of the appropriate code, standard, or rating method to see what it says. In many instances, the user(s) will have a good feel for exactly what the problem is (e.g., the code official might have told them already that a certain method does not comply with a certain section of a certain code). Codes, standards, and rating methods are essentially legal documents and the exact wording of the text is very important.

If the user suspects the existence of a barrier to one of their innovations (based on use of one of the three barrier identification methods), the next action is to obtain a copy of applicable code(s), standard(s), or rating method(s). It is important to obtain the actual document that might contain the barrier to have the exact wording of any requirement and any exceptions, alternatives, or options that exist in the document. Obtaining these types of documents can be costly if the user has to purchase them. The CSI team does maintain a library of some codes and standards such as the major ASHRAE and ICC (International Code Council) standards/codes. But the CSI team does not have a copy of every code, standard, or rating method that might be an issue. Consultation with other BA research teams or other building science practitioners may provide the relevant language needed. 



\subsection{Overcome the Barrier}
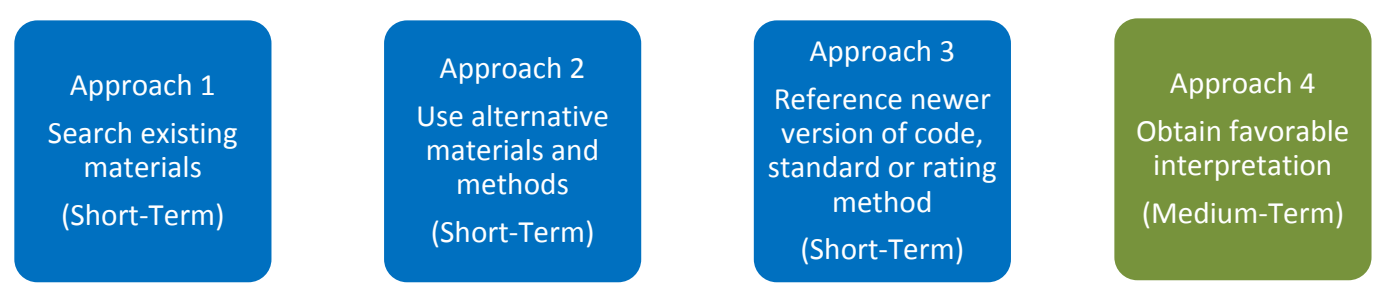

Approach 5

Change the code,

standard, or

rating method

(Long-Term)

There are five approaches to overcoming a code, standard, or rating method barrier (including short-, medium-, and long-term approaches). These five approaches are:

1. Search existing materials and find permissive language.

2. Utilize Alternate Materials and Methods clauses, and/or plead Special Circumstances.

3. Direct enforcement officials to newer versions of the code, standard, or rating method.

4. Obtain a favorable interpretation.

5. Change the code, standard, or rating method.

One of the key differentiating features of these approaches is their time frame. Some approaches can be attempted quickly. Others may take years for success to be achieved. The user should plan ahead and consider their desired time frame for using the innovation in deciding what approach or approaches to take in overcoming the barrier.

\subsection{Overcoming Barriers, Approach 1: Search Existing Materials (Short-Term Solution)}

There is an abundance of material already written on high performance homes and energy efficient measures and techniques. Some of this material can be used to validate an existing or new innovation.

Users facing a potential barrier should ask themselves if any other building science practioners, BA team members, or partners has likely faced this barrier and if so, what did they do? What about other DOE programs or industry partners that have an interest in this type of innovation? What would they recommend?

\subsubsection{How}

1. Discuss the barrier within your own BA research team (if applicable).

2. Check the BA Solution Center (BASC) at http://basc.pnnl.gov/.

3. Contact other BA research teams and/or national laboratories to discuss the barrier and any available solutions using the links to the research teams and national laboratories listed at http://www1.eere.energy.gov/buildings/residential/ba research teams.html. 
4. Contact CSI at CSIteam@pnnl.gov to discuss the barrier and any material available to assist.

\subsubsection{Example}

DOE's BECP maintains a resource center at http://www.energycodes.gov/resource-center. One of the items featured in the Resource Center is "Code Notes" to assist code officials with areas in the code that have been difficult to understand. Codes notes may be found at http://www.energycodes.gov/resource-center/publications?f]0]=field document tyoe $\% 3 \mathrm{~A} 324$. Two examples of code notes that may be of use to users are those related to duct testing in new residential construction (http://www.energycodes.gov/duct-testing-new-residential-construction-code-notes) and ducts in conditioned spaces (http://www.energycodes.gov/ducts-conditioned-spaces-code-notes).

\subsection{Overcoming Barriers, Approach 2: Utilize Alternative Materials and Methods Clauses and/or Plead Special Circumstances (Short-Term Solution)}

Codes, standards, and rating methods have never addressed all the possible ways a home might be designed and built and probably never will. But this is recognized within the regulatory community and therefore many of these documents have a clause that explicitly allows the use of alternative materials and methods of construction. Code officials can listen to arguments about an innovation (plead special circumstances) and make their own decision as to whether or not to allow the innovation with knowledge that the innovation is not directly addressed in an adopted document. It is more likely that this will occur if a code official has a good working relationship with the user and if the code official trusts the user. It is also more likely that this will occur if the user can explain the innovation in terms that are understandable to the code official and if the user can adequately discuss any risks that might be associated with approval of the innovation.

\subsubsection{How}

The user should carefully check the language of the code, standard, or rating method that contains the barrier to determine if the document contains any sort of alternative approaches or exceptions to the barrier. The user should also consider their relationship with the code official enforcing the document with the barrier in it and whether or not a well-planned discussion of the innovation and the barrier might help overcome the code official's reluctance to approve the innovation.

A user that does figure out how to use an alternative materials and methods clause or how to convince a code official to accept an innovation, despite a potential barrier, should notify the CSI team so this can be documented. The CSI team can post successful acceptance of special circumstance innovations in the BASC to assist other users including code officials.

\subsubsection{Example}

The key to use of this method is documentation. Users must be prepared to document why the innovation should be considered an alternative approach or why the innovation should receive special 
consideration. See Appendix B for an example form developed by Pierce County, WA for builders and contractors to complete using the Alternative Materials approach.

\subsection{Overcoming Barriers, Approach 3: Direct Enforcement Officials to Newer Versions of Code, Standard, or Rating Method (Short- Term Solution)}

Typically, newer codes, standards, and rating methods deal better with newer materials, constructions, and practices than older codes and standards, simply because knowledge of those newer concepts is more widespread as time passes. But at any given time, many states and jurisdictions will still have old documents on their books and those documents may embody barriers that are not present in newer versions of the same documents. One approach users can take, in some cases, is to direct officials to those newer documents EVEN IF THE NEWER VERSION IS NOT ADOPTED IN THE JURISDICTION IN QUESTION. The code official may be swayed by the fact that the organization that creates the document has seen fit to change the document to accommodate the innovation and therefore may accept the innovation.

\subsubsection{How}

The key to this approach is to find newer versions of the code, standard, or rating method that do allow the innovation. For example, if the 2009 IECC does not permit something, perhaps the 2012 IECC has the solution, and perhaps the code official will allow that solution. The CSI team may be able to help identify newer codes and standards that may provide a better way to address the innovation. The CSI team may also be able to help formulate letters or emails to your code official.

\subsubsection{Example}

From a BA standpoint, the classic cases of a newer version of a code or standard being better able to deal with an innovation would be the updates of the IECC to deal properly with air sealing of the building enclosure and unvented crawlspaces. These examples are discussed in more detail in Overcoming Barriers Approach 5, but the bottom line for users is that older versions of the IRC/IECC might not address these two topics correctly, but the newer versions do. If high-performance homes are being built in jurisdictions that still have the older versions of the IECC on the books, it might be possible to point to the newer versions as examples of how these innovations should be properly dealt with and as evidence that the innovation will not result in structural, fire, safety, or other issues. The fact that there exists new code language developed through a consensus process may help.

\subsection{Overcoming Barriers, Approach 4: Obtain a Favorable Interpretation (Medium-Term Solution)}

All codes, standards, and rating methods writing organizations have a process whereby technical questions related to their documents can be answered. These may be called an interpretation or a technical question and there may be informal and formal approaches, but the purpose and likely result is the same. When there is a question whether an innovation is in conflict with a code, standard, or test method, the user may formally submit the question to the relevant interpretive body. A favorable 
response will often persuade a reluctant official to allow the innovation and can apply broadly across jurisdictions in many regions.

\subsubsection{How}

- For ASHRAE codes and standards, see https://www.ashrae.org/standards-research-technology/standards-interpretations for published interpretations and https://www.ashrae.org/standards-research--technology/standards-forms--procedures/how-to-requestan-interpretation to request a new interpretation.

- For IAPMO codes and standards, see http://www.iapmo.org/Pages/FieldServicesAssistance.aspx.

- For ICC codes and standards, see http://www.iccsafe.org/cs/Pages/opinions.aspx.

- For NFPA codes and standards, see http://www.nfpa.org/codes-and-standards/technical-questions. You will be asked to create an NFPA account to access this page.

- For SMACNA codes and standards, see http://www.smacna.org/technical/index.cfm?fuseaction=inquiry.

- Another good, but potentially costly way of both identifying and confirming codes and standards barriers is to enlist the services of an organization like the International Code Council (ICC) Evaluation Service (ES). This organization can look at a proposed innovation and identify potential issues the innovation may face within the family of ICC I-codes. If no issues are found, an ICC-ES report can be a very powerful tool to use in convincing code officials that the innovation is permissible. For more information on the ICC-ES, see http://www.icc-es.org/. (See Appendix C for ICC-ES Evaluation Report Generation Process Flow Chart. IAPMO offers a similar service at http://www.iapmoes.org/Pages/default.aspx.

\subsubsection{Example}

The ICC-ES offers a complete listing of evaluation reports they have produced at http://www.icces.org/Evaluation_Reports/. Beginning with the listings by Construction Specification Institute category, and picking Division 07 for Thermal and Moisture Protection, then Division 0714 for Fluid Applied Waterproofing brings one to the listing at http://www.icc-

es.org/Reports/index.cfm?csi_id=299\&view details of 18 products in this category that have been evaluated. The complete evaluation report may be downloaded for each product.

\subsection{Overcoming Barriers, Approach 5: Change the Code, Standard, or Rating Method (Long-Term Solution)}

As discussed in Approach 3, all codes, standards, and rating methods change over time. One way to ensure that an innovation is allowed under a particular code, standard, or rating method is to change the code, standard, or rating method in question to explicitly allow the innovation. In the medium to long term, proposals to change all these regulations can be submitted by anyone as long as the proper process is followed. This can be a long and involved process for a user with no guarantee of success. However, there are many organizations interested in energy efficiency in residential buildings and these organizations can help with the legwork if the user identifies the barrier and 
provide relevant documentation and justification for an amendment. Note that just because a code, standard, or test method writing organization changes its document does not mean that a state or local jurisdiction will adopt it. States and local jurisdictions have their own timelines for considering and adopting codes and standards and those timelines may lag what happens at the national level considerably.

\subsubsection{How}

To do this requires someone to:

1. Identify the text of the code or standard section that needs to be changed.

2. Develop new proposed text for the code or standard section.

3. Provide analysis and justification for why the code or standard needs to be changed.

4. Identify and engage other stakeholders, seeking additional input by interested parties and addressing concerns of potential objectors.

5. Document the proposed change and justification on the required forms.

6. Submit the required forms to the code or standard writing organization.

7. Work with stakeholders and interested parties to develop coordinated support and minimize opposition to the proposal.

8. Attend hearings to speak in support the proposed change. The presence of technical experts at such hearings can be crucial.

9. Provide additional documentation and discussion as required in follow on hearings.

The CSI team may be able to help users identify suitable partners for developing and submitting these changes.

\subsubsection{Examples}

There are several examples of BA research teams making changes to codes and standards to insure that BA innovations can be implemented. These include air sealing of the building enclosure and unvented crawlspaces. (See Appendix D and E for example flow charts of the I-Code Development Process and the Standards Development Process.)

\subsubsection{Air Sealing of the Building Enclosure}

Background: Air sealing of building enclosures has been in energy codes dating back to ASHRAE Standard 90-75, the forerunner of almost all US energy codes and standards. Standard 90-75 states in Section 4.5.4 Caulking and Sealants, that "Exterior joints around windows and door frames, between wall cavities and window or door frames, between wall and foundation, between wall and roof, between wall panels, at penetrations or utility services through walls, floors, and roofs, and all other openings in the exterior envelope shall be caulked, gasketed, weatherstripped, or otherwise sealed." That language (or similar language) was found in all versions of model energy codes for home until recently. 
Barrier: BA research teams have long focused on improving building envelope air sealing. These teams felt that the existing code language, while adequate if truly applied to every conceivable opening in the building envelope, could be improved by providing additional detail and guidance. In particular, BA teams promoted the importance of a thermal bypass checklist to improve air barriers.

Resolution: BA research teams effectively demonstrated the importance of inspecting specific building features for thermal bypasses and that led the Environmental Protection Agency (EPA) to include such a checklist in its ENERGY STAR for Homes Version 3 specifications in 2006. A code change proposal was developed for the IECC and a similar checklist was implemented in the 2009 IECC. The requirements in the 2009 IECC include both a greatly expanded list of areas of the building envelope that must be sealed (in Section 402.4.1) as well as a requirement for a demonstration of the envelope tightness by one of two methods - testing or visual inspection (in Section 402.4.2).

\subsubsection{Unvented Crawlspaces}

Background: Many homes in the United States are built with crawlspaces. The practice of venting crawlspaces is very common in the construction industry. However, in humid climates, vented crawlspaces can lead to moisture damage. Sealing the crawlspace to make an unvented crawlspace can reduce this potential.

Barrier: Builders were unwilling to use unvented crawlspaces due in part to the fact that existing codes did not allow them.

Resolution: BA research teams investigated a number of codes and standards and determined that the codes do allow unvented crawlspaces under certain conditions. Specifically, codes allow unventilated crawlspaces when there is a continuous ground cover, perimeter walls are insulated, and the crawlspace is conditioned. BA research teams conducted a study that showed that unvented, conditioned crawlspaces with insulation on the perimeter perform better in terms of safety and health (pest control), comfort (warm floors, uniform temperatures), durability (moisture), and energy consumption than passively vented crawlspaces with sub-floor insulation. This study justified new language clarifying unvented crawlspace requirements in the 2004 Supplement to the 2003 IECC and the 2004 IRC and led to increased acceptance of unvented crawlspaces. 


\subsection{Building America CSI Team Involvement}

Once the user has identified what they believe to be a code, standard, or rating method barrier, the existence of that barrier can be conveyed to the BA CSI team. The CSI team can track barriers to BA innovations across the program. The CSI team may also be able to help confirm the existence of the barrier through more detailed consideration of the language of the code, standard, or rating method. The CSI team may also be able to help prepare for overcoming the barrier. Existing or newly developed materials to overcome the barrier will be uploaded in the BASC.

As part of the notification of the CSI team, please let them know if you have a copy of the document that contains the barrier. The CSI team would like to document the version and section of the specific document that contains the language to a barrier.

\subsection{How}

Submit barriers to innovations identified by the methods and tables described in this document or by other means to CSIteam@pnnl.gov.

Given the relative newness of the BA CSI team as a functioning entity, there are no examples of notification provided by users. However, just about any documentation from a simple email to a copy of the forms or information used to determine the barrier will do. Electronic submittal is preferable to a phone call simply because an electronic submittal provides a "trail" and reduces the amount of work that the CSI team must do to track the barrier. More detail is preferable to less. The CSI team Point-ofContact (POC) at the Pacific Northwest National Laboratory, will be implementing a communication platform, in 2014, for the CSI team task force to discuss, resolve, and track barriers. 



\section{Appendix A}

List of Codes and Standards and List of Questions for Identification of Barriers 



\section{Appendix A}

\section{List of Codes and Standards and List of Questions for Identification of Barriers}

Table A.1, Table A.2, and Table A.3 provide convenient ways to document use of Barrier Identification Method 1. Table A.1 lists codes and standards and provides a place for documentation. Table A.2 is an alternative listing of codes and standards. Table A.3 is a form to use for test methods. For all the tables in Appendix A, CSI plans to make these available electronically and to solicit input from BA research teams, their partners, and industry in order to improve the tables.

\section{A.1 Terminology used in Table A-1}

\section{ASHRAE}

IAPMO

ICC

NFPA

SMACNA
American Society of Heating, Refrigerating and Air-Conditioning Engineers

International Association of Plumbing and Mechanical Officials

International Code Council

National Fire Protection Association

Sheet Metal and Air Conditioning Contractors National Association

Table A.1. Table of Codes and Standards for Identification of Barriers

\begin{tabular}{|c|c|c|c|c|}
\hline \multicolumn{5}{|c|}{ Innovation Description } \\
\hline $\begin{array}{c}\text { Code or } \\
\text { Standard } \\
\text { Organization }\end{array}$ & Code or Standard & $\begin{array}{l}\text { Publication } \\
\text { Year }\end{array}$ & $\begin{array}{r}\text { Potential } \\
\text { Conflict }\end{array}$ & $\begin{array}{l}\text { Specific chapter or } \\
\text { section that could } \\
\text { be a barrier }\end{array}$ \\
\hline ASHRAE & $\begin{array}{l}\text { Ventilation and Acceptable Indoor Air Quality in } \\
\text { Low-Rise Residential Buildings (Standard 62.2) }\end{array}$ & & Yes/No/NA & \\
\hline ASHRAE & $\begin{array}{l}\text { Energy Efficient Design of Low-Rise Residential } \\
\text { Buildings (Standard 90.2) }\end{array}$ & & Yes/No/NA & \\
\hline ASHRAE & Other code or standard-Specify & & Yes/No/NA & \\
\hline IAPMO & Uniform Mechanical Code & & Yes/No/NA & \\
\hline IAPMO & Uniform Plumbing Code & & Yes/No/NA & \\
\hline IAPMO & Uniform Solar Energy Code & & Yes/No/NA & \\
\hline IAPMO & Uniform Swimming Pool, Spa, and Hot Tub Code & & Yes/No/NA & \\
\hline IAPMO & Other code or standard-Specify & & Yes/No/NA & \\
\hline ICC & International Building Code & & Yes/No/NA & \\
\hline ICC & International Energy Conservation Code & & Yes/No/NA & \\
\hline ICC & International Existing Building Code & & Yes/No/NA & \\
\hline ICC & International Fire Code & & Yes/No/NA & \\
\hline ICC & International Fuel Gas Code & & Yes/No/NA & \\
\hline ICC & International Mechanical Code & & Yes/No/NA & \\
\hline ICC & ICC Performance Code & & Yes/No/NA & \\
\hline ICC & International Plumbing Code & & Yes/No/NA & \\
\hline ICC & International Plumbing Code & & Yes/No/NA & \\
\hline ICC & International Private Sewage Disposal Code & & Yes/No/NA & \\
\hline
\end{tabular}




\begin{tabular}{|c|c|c|c|c|}
\hline \multicolumn{5}{|c|}{ Innovation Description } \\
\hline $\begin{array}{c}\text { Code or } \\
\text { Standard } \\
\text { Organization }\end{array}$ & Code or Standard & $\begin{array}{l}\text { Publication } \\
\text { Year }\end{array}$ & $\begin{array}{l}\text { Potential } \\
\text { Conflict }\end{array}$ & $\begin{array}{l}\text { Specific chapter or } \\
\text { section that could } \\
\text { be a barrier }\end{array}$ \\
\hline $\mathrm{ICC}$ & International Property Maintenance Code & & $\mathrm{Yes} / \mathrm{No} / \mathrm{NA}$ & \\
\hline ICC & International Residential Code & & Yes/No/NA & \\
\hline $\mathrm{ICC}$ & International Swimming Pool and Spa Code & & Yes/No/NA & \\
\hline $\mathrm{ICC}$ & International Wildland-Urban Interface Code & & Yes/No/NA & \\
\hline ICC & International Zoning Code & & $\mathrm{Yes} / \mathrm{No} / \mathrm{NA}$ & \\
\hline $\mathrm{ICC}$ & Other code or standard-Specify & & Yes/No/NA & \\
\hline NFPA & Fire Code (NFPA 1) & & Yes/No/NA & \\
\hline NFPA & $\begin{array}{l}\text { Standard for the Installation of Sprinkler Systems in } \\
\text { One- and Two-Family Dwellings and Manufactured } \\
\text { Homes (NFPA 13D) }\end{array}$ & & $\mathrm{Yes} / \mathrm{No} / \mathrm{NA}$ & \\
\hline NFPA & $\begin{array}{l}\text { Standard for the Installation of Sprinkler Systems in } \\
\text { Low-Rise Residential Occupancies (NFPA 13R) }\end{array}$ & & Yes/No/NA & \\
\hline NFPA & National Fuel Gas Code (NFPA 54) & & Yes/No/NA & \\
\hline NFPA & Liquefied Petroleum Gas Code (NFPA 58) & & Yes/No/NA & \\
\hline NFPA & National Electrical Code (NFPA 70) & & Yes/No/NA & \\
\hline NFPA & $\begin{array}{l}\text { National Electrical Code } \AA \text { Requirements for One- } \\
\text { and Two-Family Dwellings (NFPA 70A) }\end{array}$ & & Yes/No/NA & \\
\hline NFPA & $\begin{array}{l}\text { Standard for Electrical Inspections for Existing } \\
\text { Dwellings (NFPA 73) }\end{array}$ & & Yes/No/NA & \\
\hline NFPA & $\begin{array}{l}\text { Recommended Practice for Protection of Buildings } \\
\text { from Exterior Fire Exposures (NFPA 80A) }\end{array}$ & & $\mathrm{Yes} / \mathrm{No} / \mathrm{NA}$ & \\
\hline NFPA & Life Safety Code ${ }^{\circledR}$ (NFPA 101) & & Yes/No/NA & \\
\hline NFPA & $\begin{array}{l}\text { Guide on Alternative Approaches to Life Safety } \\
\text { (NFPA 101A) }\end{array}$ & & Yes/No/NA & \\
\hline NFPA & $\begin{array}{l}\text { Code for Means of Egress for Buildings and } \\
\text { Structures (NFPA 101B) }\end{array}$ & & Yes/No/NA & \\
\hline NFPA & $\begin{array}{l}\text { Standard for Emergency and Standby Power } \\
\text { Systems (NFPA 110) }\end{array}$ & & Yes/No/NA & \\
\hline NFPA & $\begin{array}{l}\text { Standard on Stored Electrical Energy Emergency } \\
\text { and Standby Power Systems (NFPA 111) }\end{array}$ & & Yes/No/NA & \\
\hline NFPA & $\begin{array}{l}\text { Guide on Roof Coverings and Roof Deck } \\
\text { Constructions (NFPA 203) }\end{array}$ & & Yes/No/NA & \\
\hline NFPA & Standard for Smoke and Heat Venting (NFPA 204) & & Yes/No/NA & \\
\hline NFPA & $\begin{array}{l}\text { Standard for Chimneys, Fireplaces, Vents, and } \\
\text { Solid Fuel-Burning Appliances (NFPA 211) }\end{array}$ & & Yes/No/NA & \\
\hline NFPA & $\begin{array}{l}\text { Standard for Protection of Life and Property from } \\
\text { Wildfire (NFPA 299) }\end{array}$ & & Yes/No/NA & \\
\hline NFPA & $\begin{array}{l}\text { Standard for Determination of Fire Loads for Use in } \\
\text { Structural Fire Protection Design (NFPA 557) }\end{array}$ & & Yes/No/NA & \\
\hline NFPA & Other code or standard - Specify & & Yes/No/NA & \\
\hline SMACNA & HVAC Air Duct Leakage Test Manual & & Yes/No/NA & \\
\hline SMACNA & Other code or standard-Specify & & Yes/No/NA & \\
\hline
\end{tabular}


Table A.2. Alternative Documentation Form for Code and Standard Barriers

(Building America Innovation Title)

\begin{tabular}{|c|c|c|c|}
\hline \multicolumn{4}{|c|}{ (Building America Innovation Description) } \\
\hline Topic & Building Code and Standards & $\begin{array}{l}\text { Potential } \\
\text { Conflict }\end{array}$ & Description of Potential Conflict \\
\hline Building Code & International Building Code (IBC) & $\mathrm{Yes} / \mathrm{No} / \mathrm{NA}$ & (Describe) \\
\hline Existing Buildings & International Existing Building Code (IEBC) & Yes/No/NA & (Describe) \\
\hline Existing Buildings & ASHRAE Standard 100 & Yes/No/NA & (Describe) \\
\hline Energy & International Energy Conservation Code (IECC) & Yes/No/NA & (Describe) \\
\hline Energy & ASHRAE Standard 90.1 & Yes/No/NA & (Describe) \\
\hline Energy & ASHRAE Standard 90.2 & $\mathrm{Yes} / \mathrm{No} / \mathrm{NA}$ & (Describe) \\
\hline Electrical & International Electrical Code (IEC) & Yes/No/NA & (Describe) \\
\hline Electrical & National Electrical Code (NEC) & Yes/No/NA & (Describe) \\
\hline Fire & International Fire Code (IFC) & Yes/No/NA & (Describe) \\
\hline Fire & NFPA Fire Codes (specify) & Yes/No/NA & (Describe) \\
\hline Fuel Gas & International Fuel Gas Code (IFGC) & $\mathrm{Yes} / \mathrm{No} / \mathrm{NA}$ & (Describe) \\
\hline Green Buildings & International Green Construction Code & $\mathrm{Yes} / \mathrm{No} / \mathrm{NA}$ & (Describe) \\
\hline Green Buildings & ASHRAE Standard 189.1 & Yes/No/NA & (Describe) \\
\hline Green Buildings & National Green Building Standard & Yes/No/NA & (Describe) \\
\hline Ventilation & International Mechanical Code (IMC) & $\mathrm{Yes} / \mathrm{No} / \mathrm{NA}$ & (Describe) \\
\hline Ventilation & ASHRAE Standard 62.1 & Yes/No/NA & (Describe) \\
\hline Ventilation & ASHRAE Standard 62.2 & Yes/No/NA & (Describe) \\
\hline Performance & ICC Performance Code & Yes/No/NA & (Describe) \\
\hline Plumbing & International Plumbing Code (IPC) & $\mathrm{Yes} / \mathrm{No} / \mathrm{NA}$ & (Describe) \\
\hline Sewage & International Private Sewage Disposal Code (IPSDC) & Yes/No/NA & (Describe) \\
\hline Maintenance & International Property Maintenance Code (IPMC) & Yes/No/NA & (Describe) \\
\hline Residential Buildings & International Residential Code (IRC) & $\mathrm{Yes} / \mathrm{No} / \mathrm{NA}$ & (Describe) \\
\hline $\begin{array}{l}\text { Swimming Pools and } \\
\text { Spas }\end{array}$ & International Swimming Pool and Spa Code (ISPSC) & $\mathrm{Yes} / \mathrm{No} / \mathrm{NA}$ & (Describe) \\
\hline Zoning & International Wildland-Urban Interface Code (IWUIC) & Yes/No/NA & (Describe) \\
\hline Zoning & International Zoning Code (IZC) & $\mathrm{Yes} / \mathrm{No} / \mathrm{NA}$ & (Describe) \\
\hline
\end{tabular}


Table A.3. Matrix of Test Standard Conflicts

\begin{tabular}{llll}
\hline Topic & Product Test Standards & Potential Conflict & Description of Potential Conflict \\
\hline (Describe $)$ & (Describe) & Yes/No/NA & (Describe) \\
\hline Topic & System Test Standards & Potential Conflict & Description of Potential Conflict \\
$($ Describe $)$ & $($ Describe $)$ & Yes/No/NA & (Describe) \\
\hline Topic & Building Test Standards & Potential Conflict & Description of Potential Conflict \\
(Describe $)$ & $($ Describe $)$ & Yes/No/NA & (Describe) \\
\hline
\end{tabular}

Table A.4 provides a list of questions for use in Barrier Identification Method 3. As with all the tables in Appendix A, CSI plans to make these available electronically and to solicit input from BA research teams, their partners, and industry in order to improve the tables.

Table A.4. Question Based Approach

1. Does the BA innovation impact the structural strength of the home in any way?

a. Does it impact the ability of the home to withstand snow loads?

b. Does it impact the ability of the home to withstand wind loads?

c. Does it impact the ability of the home to withstand earthquake loads?

d. Does it impact the ability of the home to withstand flooding?

2. Does the BA innovation impact the fire resistance of the home in any way?

a. Does it increase the likelihood of fire ignition?

b. Does it increase the likelihood of flame spread within the home?

c. Does it increase the load of combustible material?

d. Does it increase the likelihood of flame spread to neighboring structures?

3. Does the BA innovation impact the ability of fire and emergency personnel to access the home in any way?

a. Does it involve electrical wiring in a place where it would not be expected in a typical new home?

b. Does it make it harder for fire/emergency personnel to access the inside of the home?

4. Does the BA innovation impact the durability of the home in any way?

a. Does it impact moisture resistance?

b. Does it impact termite resistance?

c. Does it increase the potential for mold?

5. Does the BA innovation impact the indoor air quality of the home in any way?

a. Does it impact the ability of the home to bring in outside air?

b. Does it impact the ability of the home to exhaust inside air?

c. Does it impact the ability of the home to mix inside air with outside air?

d. Does it impact the ability of the home to "dilute" spot sources of contaminants?

e. Does it impact the humidity levels in the home?

f. Does it impact of use of combustion appliances in any way (gas stoves, gas furnaces, fire places, wood stoves)?

g. Does it introduce new sources of contaminants into the home? 
6. Does the BA innovation impact the water usage of the home in any way?

a. Does it impact indoor water quality?

b. Does it impact indoor water quantity?

c. Does it impact the time it takes hot water to reach a faucet or showerhead?

d. Does it impact exterior water quality?

e. Does it impact exterior water quantity?

f. Does it impact exterior runoff?

7. Does the BA innovation impact sewage from the home in any way?

a. Will there be more sewage?

b. Will there be the potential for more clogs?

8. Does the BA innovation impact the dimensions of the home in any way?

a. Does it lead to thicker walls (meaning thicker door frames, window sills, smaller interior space for same exterior space, etc?)

b. Does it lead to higher rooflines?

9. Does the BA innovation require changes to existing construction practice?

a. Does it require new techniques?

b. Does it require new materials?

c. Does it require new equipment?

d. Does it require new inspection or testing?

10. Does the BA innovation impact the energy efficiency of the home in any way?

11. Would the BA innovation be considered "green"?

12. Would the BA innovation impact the cost of the home in any way? 



\section{Appendix B}

Alternative Methods and Material Documentation Form Used in Pierce County, Washington 



\section{Appendix B}

\section{Alternative Methods and Material Documentation Form used in Pierce County, Washington}

\section{Alternate Method or Material Bulletin \# 28 \\ Department of Planning and Land Services, June 2010 \\ Division of Building Safety and Inspection for 2009 I Codes}

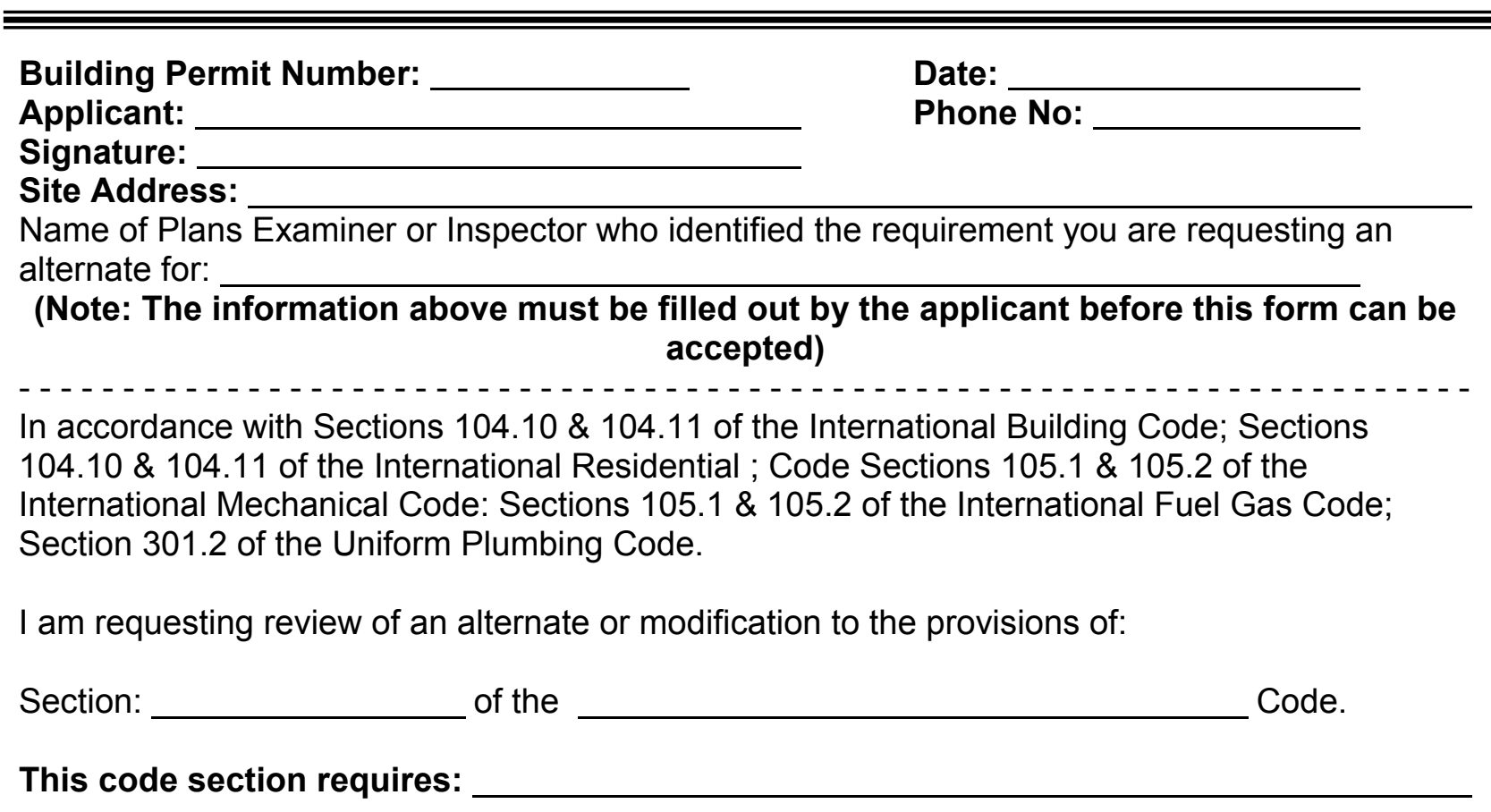

Proposed Alternate: (Include drawings to clearly illustrate request, before and after if appropriate)

Reason for Request:

Every effort will be made to provide a verbal interpretation within one (1) working day upon receipt of this request. Appeals from accessibility requirements of IBC Chapter- 11 do not relieve applicant from the obligations to provide access under the Federal ADA laws. 


\section{Division of Building Safety and Inspection \\ Request for Alternate Method or Material \\ Staff Use Only}

Date Received:

Evaluation of Proposal by Plans Examiner and/or Building Inspector:

Suitability:

Strength:

Effectiveness:

Fire Resistance:

Durability:

Safety:

Sanitation:

Recommended Action: APPROVE __ DENY _ B By:

Conditions:

Additional Information on Proposed Alternate:

Supervisor Concurrence:

Date: 


\section{Appendix C}

Alternative Methods and Material Documentation, ICCES Flow Chart 



\section{Appendix C}

\section{Alternative Methods and Material Documentation, ICC-ES Flow Chart}

ICC EVALUATION

Why Look for ICC-ES ${ }^{\oplus}$ Evaluation Reports and Marks of Conformity

ICC-ES Evaluation Report Generation Process

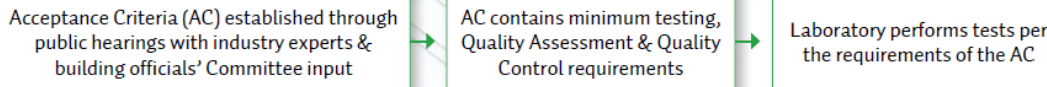

Acceptance Criteria (AC) established through AC contains minimum testing, public hearings with industry experts \& building officials' Committee input

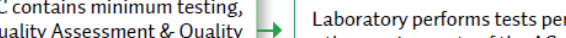
Control requirements

Test reports, calculations \& QA/QC documents are submitted to Accredited Product Certification Agency ICC-ES

ICC-ES checks data for compliance to AC \& Code

\section{ICC-ES issues \\ Evaluation}

Report

ICC-ES performs audits

Test Laboratory Report Generation Process:
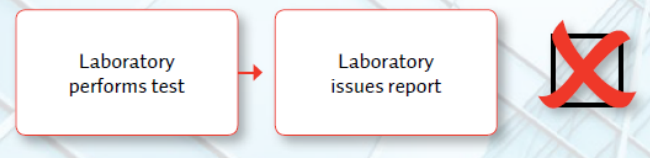

This diagram illustrates the differences between the ICC-ES and Test Laboratory evaluation processes.

The thoroughness of the ICC-ES evaluation process provides peace of mind when considering building products for approval.

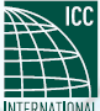

http://www.icc-es.org/PDF/ES-Reports_vs_LabReports.pdf 



\section{Appendix D}

\section{International Code Development Process Flow Chart}





\section{Appendix D}

\section{International Code Development Process Flow Chart}

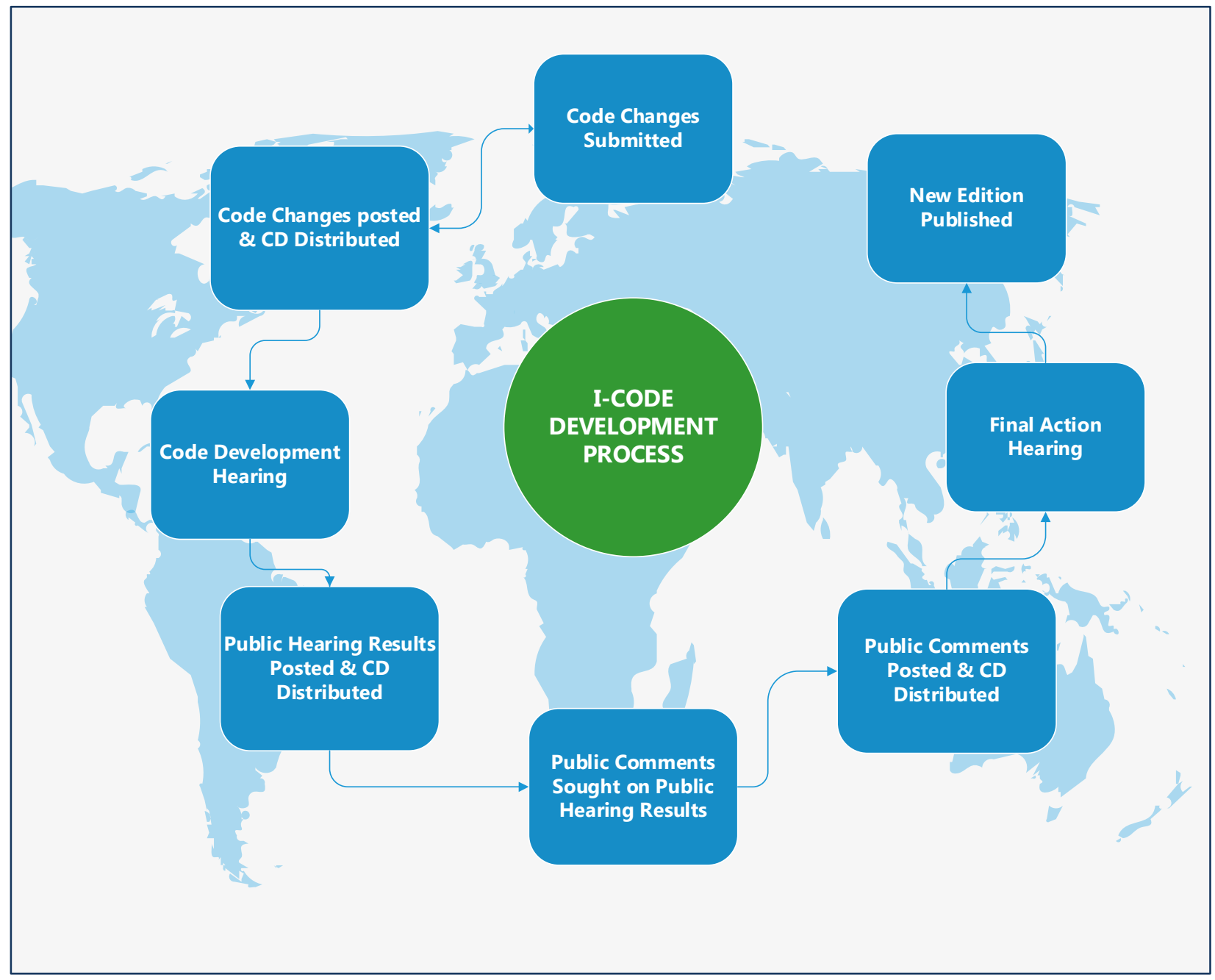

D. 1 



\section{Appendix E}

\section{Standards Development Process Flow Chart}





\section{Appendix E}

\section{Standards Development Process Flow Chart}

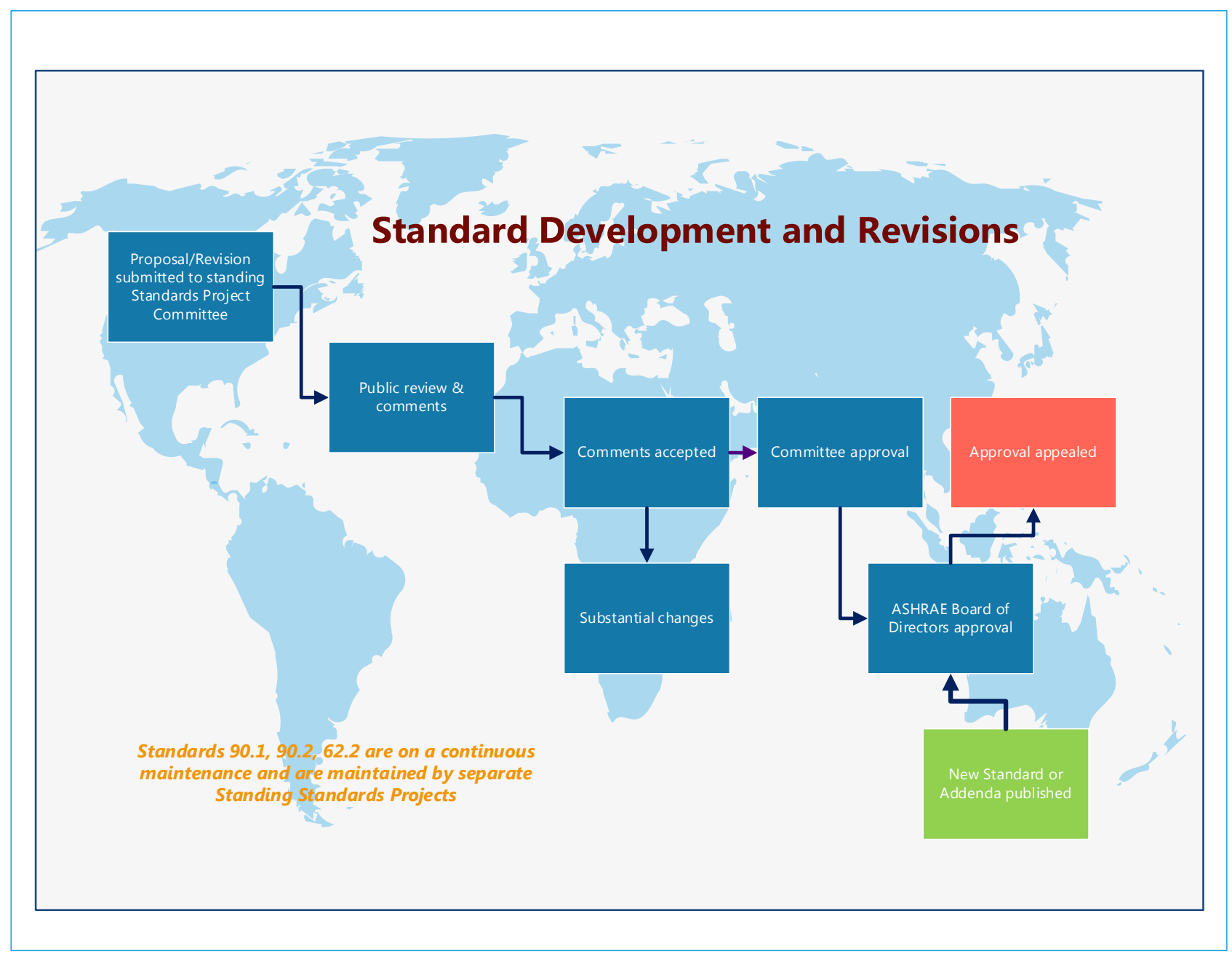




\begin{tabular}{l|l} 
u.s. DEPARTMENT of & Energy Efficiency \&
\end{tabular} 르르 Renewable Energy

\section{EERE Information Center}

1-877-EERE-INF (1-877-337-3463)

www.eere.energy.gov/informationcenter

PNNL-22755 • September 2013

Printed with a renewable-source ink on paper containing at least 50\% wastepaper, including $10 \%$ post-consumer waste. 